\title{
QUANTITATIVE ESTIMATION OF THE MACROPSYCHOLOGICAL STATE OF MODERN RUSSIAN SOCIETY
}

\author{
Andrey V. Yurevich, \\ Dmitry V. Ushakov
}

Institute of Psychology, Russian Academy of Sciences Moscow

The authors give the quantitative estimation of the macropsychological state of modern Russian society based on its political, social and economic characteristics. For these purposes the composite index of the macropsychological state of society is developed. It combines two secondary indexes such as a societal psychological stability index and a societal socio-psychological well-being index.

Keywords: economic determinism, macropsychology, psychological state of society, composite index, social well-being, social optimism, reforms.

\section{Quantitative Estimate}

\section{of the Psychological State of Society}

During the first years of the reforms, the Russian social identity was characterized by "economic determinism", i.e., perception and explanation of events occurring within a socium as mostly determined by economical causes. Practically all the main goals that were assigned to society at the start of the reforms - market economy, GDP growth, stronger ruble, lower inflation, and so on, - were of purely economic nature, whereas such problems as acute social injustice, growing crime rates, corruption, degradation of public morality, social and physical defenselessness of the citizenry, and others, though not neglected by authorities and media, were nevertheless seen as secondary. It would certainly be absurd to deny the extreme importance of the abovementioned economic goals, but their attainment per se does nothing to secure the well-being of the citizens, the main aim of any reforms. For example, it is a rhetorical question whether we can view a country as a happy one where there is steady GDP growth but population numbers decline from year to year. 
Despite the obvious defects of the "economic determinism", which Alexis de Tocqueville exposed to sharp criticism, Karl Polanyi described as "an economic fallacy", and M. Rats called "a Marxist hangover," (Rats, 1997), this style of explanation of processes in society persists to this day, as is evident, for example, from the latest book penned by Yegor Gaidar $^{1}$. At the same time, the present-day socio-humanitarian science clearly needs to have a more versatile and multidimensional perspective of society and to engage in a multiaspect analysis of factors influencing the events in the socium and its prospects.

One of these factors is the psychological state of society ${ }^{2}$, quite comparable in importance with its political and economic characteristics. To evaluate this state, we have developed a composite index of the macropsychological state of society that combines two secondary indexes - a societal psychological stability index and a societal sociopsychological wellbeing index, each of which, in turn, integrates three primary indexes (Fig. 1). ${ }^{3}$

As primary indexes we considered indicators that were, firstly, relevant to the macropsychological state of society and expressive of it, and, secondly, capable of being evaluated by quantitative indicators available from statistical manuals. In this regard, calculating this index goes on

1 A curious and symptomatic fact is that this "hangover of Marxism" is characteristic of the Russian liberal economists to a no lesser extent than it is of its few remaining adherents, though the first have always formally rejected Marxism. However, in such cases we can accept the "protective" nature of narrow economic explanations that make it possible to explain the reformers' actions by an "objective" economic necessity which relieves them of their personal responsibility for those actions (Gaidar, 2006).

2 Studying this state falls within the purview of macropsychology, a relatively new area of the psychological science (Yurevich, 2006, p. 5-14). While the traditional objects of psychological studies are isolated psychic processes (memory, attention, thinking and others), personality, large and small groups, macropsychology studies psychological processes relevant to society as a whole. This is the main difference between macropsychology and social psychology, which "ends" at the level of large social groups. The novel ty of this area of psychology is rather relative, as the works by the founders of psychology and social psychology - Gustav Le Bon's The Psychology of Peoples and Ethnic Psychology by Wilhelm Wundt - were devoted precisely to macropsychological subjects.

3 The primary indexes in this Figure could be grouped in other ways too. For example, they may be represented as secondary indexes: 1) psychic disorders and mortality from diseases of the nervous system and sense organs; 2 ) social orphanhood and family stability; 3 ) homicides and suicides.

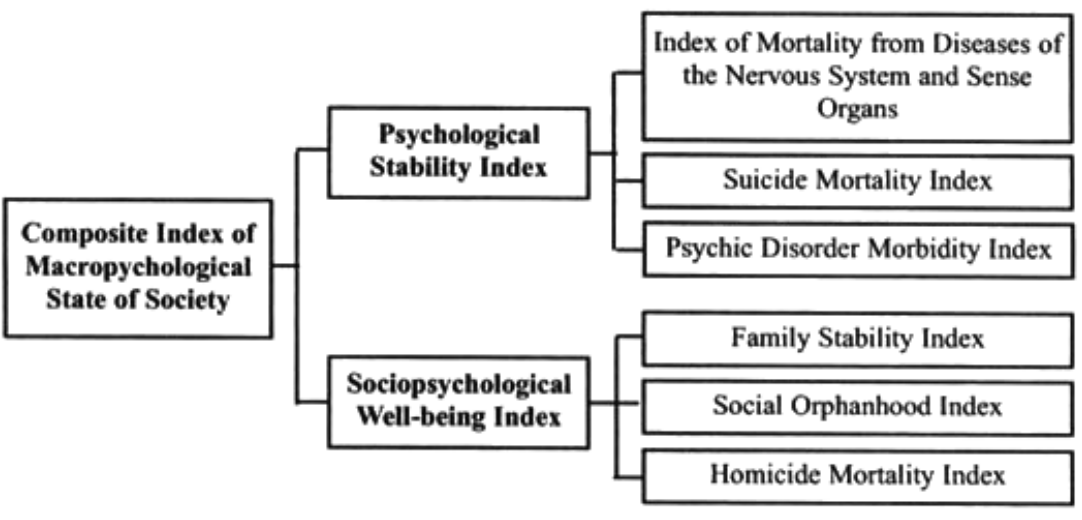

Figure 1. Structure of the Composite Index of Macropsychological State of Society

with a tradition that has a direct relation to psychological science even though it originated elsewhere (Gundarov, 2001). In particular, as S. Sulakshin says, «scientific literature knows of attempts to indirectly describe the psychological state of society via quantitative measurements of deviant behavior covered by statistics: murders, suicides, manifestations of behavioral aggressions» (Rats, 1997, p. 76-77). We can point to Emile Durkheim's most resonant work, Suicide: A Study in Sociology, as the first attempt at this kind of investigation.

At first sight, this approach - estimation of the psychological state of society based on its social manifestations recorded in statistics - is essentially different from the tradition of calculating quantitative indicators that took shape in the psychological science itself. But these differences should not be overestimated. In cases when a psychologist forms a judgment, for example, about a person's psychological qualities on the ground of their testing, he also evaluates concealed psychological essences by their behavioral or verbal manifestations. In this sense, estimation of the psychological state of society on the basis of statistical data is not fundamentally different from psychologists' everyday research practices. There is one exception though, which consists in the fact that the "concealed psychological essence" in the former case is the psychological state of society as a whole, rather than that of a separate individual. 
A similar approach becomes quite characteristic of the modern socio-humanitarian science, and, in parallel, is spreading to other disciplines, such as sociology, demography, and others. Sociologists calculate indexes of social moods, social optimism, satisfaction with life, population's social self-awareness, etc (Balatsky, 2005a; Boyko, 1985), which have a clearly expressed psychological component ${ }^{4}$. Demographers calculate such indexes as the national vitality coefficient ${ }^{5}$ that also has a psychological tinge. Quality of life is a broadly studied phenomenon in this field as well as the others, for example subjective well-being. Psychologists are active in doing research into these as well (Biderman, 1970; Keltner, 1993). Such tendencies in different socio-humanitarian disciplines share a common denominator - the wish to quantitatively estimate society's social and psychological characteristics, which traditionally were of qualitative nature. Another aim is to emphasize their importance for the authorities and the social consciousness in the most convincing manner, to wit, in the shape of quantitatively recorded tendencies $^{6}$. We should also make some comments about the primary indicators put at the base of calculation of the composite index of macropsychological state of society.

- Firstly, each of them does not have a solely psychological significance, and, as a rule, is used with a meaning other than psychological within the framework of existing traditions. But apart from these meanings, each of them certainly has a psychological significance. The primary indicators, on the basis of which the first secondary index is calculated, are more relevant to the level of personality and characterize its psychological stability, while the primary indicators put at the base of the second secondary index are relevant to the level of interper-

${ }^{4}$ Let us stress that even the primary components of these indexes are largely psychological. For example, Balatsky's satisfaction-with-life index includes such primary indicators as creative self-realization and effective informal social contacts (friendship, mixing, mutual understanding, sex, etc.)

5 It must be said that, written by a professional demographer, this work is devoted to causes of the worsening demographic situation in present-day Russia and attaches primary importance to socio-psychological factors (Sulakshin, 2006)

6 Sulakshin, for one, writes about his country vitality coefficient: "The introduction of this parameter is also explained by the wish to operationalize, in the managerial and legal sense, the recognition of human life as the top measure of state managerial success" (Sulakshin, 2006, p. 27). sonal relations, characterizing the degree of their well-being, stability of society's "primary cells" (families), its characteristic attitude towards children and human life in general, the existing moral and psychological atmosphere, etc. Moreover, each of the primary indicators is an "aggregate phenomenon with a primary "shrinkage", compression of social information" (Balatsky, 2005a, p. 43).

- Secondly, the composite index of the macropsychological state of society integrates far from all indicators with a macropsychological meaning. Generally, it is rather difficult to find an indicator of importance for a society and therefore recorded in statistical manuals, which would be totally devoid of any psychological significance. At the same time, the drafting of composite indexes implies certain natural limitations: no one can embrace the boundless. You cannot embrace all the more or less relevant indicators that, in addition, possess a different degree of psychological relevance. As stressed by E. Balatsky, "the number of factors should not be too great (not more than 15), for otherwise your index will become nontransparent, while interpreting quantitative results will turn into a laborious procedure" (Ibid.). This is why we included only those statistical indicators in our composite index that possessed an utmost psychological relevance.

- Third, far from all indicators proved acceptable for their calculation within the context of the system existing in Russia. For example, alcohol abuse level is a clearly relevant characteristic of the psychological state of society. However, Russian official statistics takes the number of persons that applied to narcologists as an appropriate indicator. Since this tradition, unlike the tradition of plentiful alcohol consumption, is not characteristic of Russia (very few heavy drinkers in Russia come to narcologists even though they have every reason to do so), the Russians appear, in this respect, a nation with a low consumption of alcohol, something that is clearly at odds with per capita alcohol consumption statistics.

- Fourth, "soft" indexes (indexes of social self-disposition, indexes of social moods, and others, as calculated by Russian sociological services) are phenomena possessing the highest degree of psychological relevance. But they are calculated on the basis of selective polls, "tied" to definite samples and so cannot be correlated with general statistical indicators. Therefore, while not discarding a possibility of calculating and using such indexes in the future, at this stage we restricted ourselves to "hard" 
indexes calculated on the basis of general Russian statistical indicators. It must be mentioned that the overly "pliant" indicators often capture accidental social changes, so-called "white noise", and only disorient the analyst (Ibid., p. 46). So, the "hard" indexes have definite advantages in this sense too.

The primary indexes are calculated on the basis of specific exponents, i.e., those correlated with the population size. All values of exponents are converted into points from 1 to 10 (the higher the point the higher the value of a corresponding indicator of the psychological state of society). The normalization - the conversion of exponents into points - was made by comparing Russian indicators with similar indicators for more advanced countries (in accordance with the UN classification) drawn up by the appropriate international organizations. A primary index, the normalized estimation of an exponent in points from 1 to 10 , is calculated with the help of this formula:

$$
Y=9 x \frac{V_{\max }-V_{y}}{V_{\max }-V_{\min }}+1 .
$$

Where $V_{y}$, is the value of a concrete indicator for Russia for a certain year, $V_{\max }$ is the maximal value of the indicator among countries in this group during the period under consideration (1990-2004), $V_{\min }$ is the minimal value of the appropriate indicator in the said international context. The secondary indexes and the composite index were calculated as the arithmetic mean of indexes of a lower order.

We discovered a high correlation of the primary indexes between themselves, which means that there is a high coordination of different indicators of the macropsychological slate of society (Table 1).

The high degree of correlation between the primary indicators is a sign of their mutual influence. Simultaneously, it means that it is legitimate to bring them together and consider them as an expression of a single whole - the macropsychological state of society. Our factor analysis corroborates this conclusion (Figure 2).

The first factor explains almost $72 \%$ of dispersion and satisfies the Kaiser criterion surpassing its proper value threshold at 1.0. Thus, the macropsychological indicators form a structure with an expressed general factor. Though failing to attain the statistical significance level, the two-factor solution merits attention and lends itself to an unambiguous meaningful interpretation. In the first factor, all parameters prove load-

Table 1

Pearson Correlation Coefficients of Primary Indicators

\begin{tabular}{|c|c|c|c|c|c|c|}
\hline Indicator & 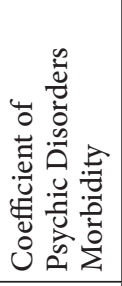 & 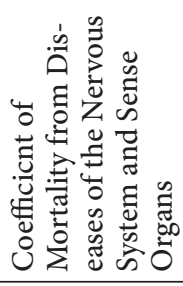 & 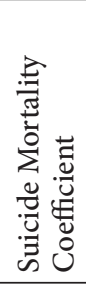 & 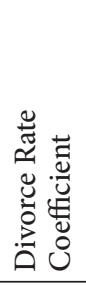 & 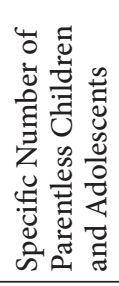 & 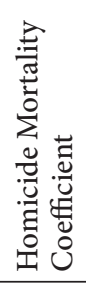 \\
\hline $\begin{array}{l}\text { Coefficient of Psychic } \\
\text { Disorders Morbidity }\end{array}$ & & 0.581 & 0.646 & 0.41 & 0.97 & 0.664 \\
\hline $\begin{array}{l}\text { Coefficient of Mortality } \\
\text { from Diseases of Ihe } \\
\text { Nervous System and } \\
\text { Sense Organs }\end{array}$ & 0.581 & & 0.756 & 0.492 & 0.684 & 0.865 \\
\hline $\begin{array}{l}\text { Suicide Mortality } \\
\text { Coefficient }\end{array}$ & 0.646 & 0.756 & & 0.284 & 0.716 & 0.905 \\
\hline $\begin{array}{l}\text { Divorce Rate } \\
\text { Coefficient }\end{array}$ & 0.41 & 0.492 & 0.284 & & 0.434 & 0.57 \\
\hline $\begin{array}{l}\text { Specific Number } \\
\text { of Parentless Children } \\
\text { and Adolescents }\end{array}$ & 0.97 & 0.684 & 0.716 & 0.434 & & 0.725 \\
\hline $\begin{array}{l}\text { Homicide Mortality } \\
\text { Coefficient }\end{array}$ & 0.664 & 0.865 & 0.905 & 0.57 & 0.725 & \\
\hline
\end{tabular}

Source: The authors' calculations.

ed with the exception of one - the number of divorces - which manifests itself as the sole parameter with a high load in the second factor.

We also performed an additional analysis of the dynamism characterizing the psychological state of society index. Our original assumption was that certain index parameters could react to changes in this state faster than others. To verify the assumption, we calculated the regressive relation of the dynamic characteristics of index components: an annual increment or decrement in their value as well as a forecasted index value (for the next year). The strongest predictor of index change was the growth or decline in the number of murders $\left(R^{2}=0.501, p<0.004\right)$. Thus, a change in the crime situation of society reacts most sensitively to incipient changes in its psychological state. 


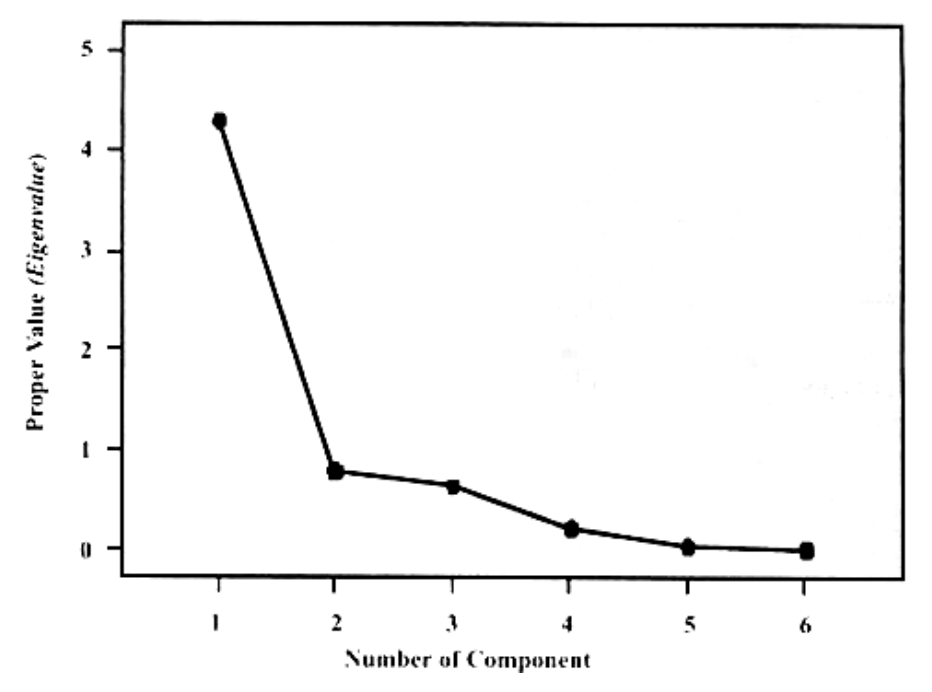

Source: The authors' calculations.

Figure 2. Eigenvalues of Factors in the Factor Analysis of Components of the Composite Index of the Macropsychological State of Society

On the whole, our statistical and mathematical analysis warrants the conclusion that all the society's macropsychological characteristics combined in the composite index express the interconnected aspects of its psychological state that differ, however, in their dynamical manifestations. Some of them show a quicker reaction to its change, while others possess greater latency.

\section{Psychological State of Current Russian Society}

The composite index provides a quantitative estimation of the dynamics of Russian society's psychological state during the reform years (Figure 3). As is evident from Fig. 3, Russian society's psychological state estimated with the help of the composite index was steadily deteriorating from 1991 to 1994; then it improved annually till 1998, after which it deteriorated again till 2002, whereupon it displayed a tendency towards an improvement (the index value for 2005 was not calculated for the lack of appropriate primary statistics).
This dynamics is easy to explain on the basis of the general tendencies in the development of Russian society and their reflection in the psychological state of the population. The radical sociopolitical reforms, the market transition, the "shock therapy" and the like caused maladjustment in the main part of the population, which led to an annual deterioration in its psychological state. Here is an example of some widespread descriptions of the first reform years: "While seeking to assimilate the Russian civilization into the Western one, to substitute the value and behavioral matrixes, attempts to encroach upon... human motivation sources, to impose other, alien civilizational accumulations can only lead to stress, resistance and psychological discomfort" (Sulakshin, 2006, p. 46). It is symptomatic that those years arose such social identification of Russian fellow citizens as "a victim of the reforms" (Gundarov, 2001). In this connection we may also quote a conclusion drawn by an economist rather than a psychologist: "the stability of a socioeconomic system is stipulated by society's homeostasis achieved in the process of satisfaction of the basic human instincts - self-preservation, self-reproduction (perpetuation of the species) and self-realization (self-expression)" (Sulakshin, 2006, p. 43-44). This conclusion is consonant with Abraham Maslow's motivation theory (although the author of the above quotation recalls in this connection the Sufic traditions rather than Maslow's theory). It is also indicative that in those years the Russians saw social security and possibility of receiving skilled medical aid (Mozgovaya, 2001) as their top values, ones corresponding to security requirements in Maslow's requirements hierarchy.

By 1994, the majority of the Russian population psychologically adapted to the reforms, something that was expressed in a tendency towards an improvement in its psychological state ${ }^{7}$. Other studies identified that as well. For example, the use of semantic differential demonstrated that "after the collapse of the estimation in the 'meaningfulness of life' factor, a collapse that marked the four previous years, the year 1995

\footnotetext{
It stands to reason to assume that either the psychological adaptation was the consequence of the economic and sociopolitical ones, or that it was independent (one may psychologically adapt and get used to realities, to which one can hardly adapt economically), or, and more likely than not, both took place. It must also be said that, according to the studies, "the leading component of adaptation is not so much today's positive self-disposition, but a sensation that well-being has prospects and will be 'prolonged"' (Dudchenko, Mytil, 2001, p. 615). And that is the psychological state of a person.
} 


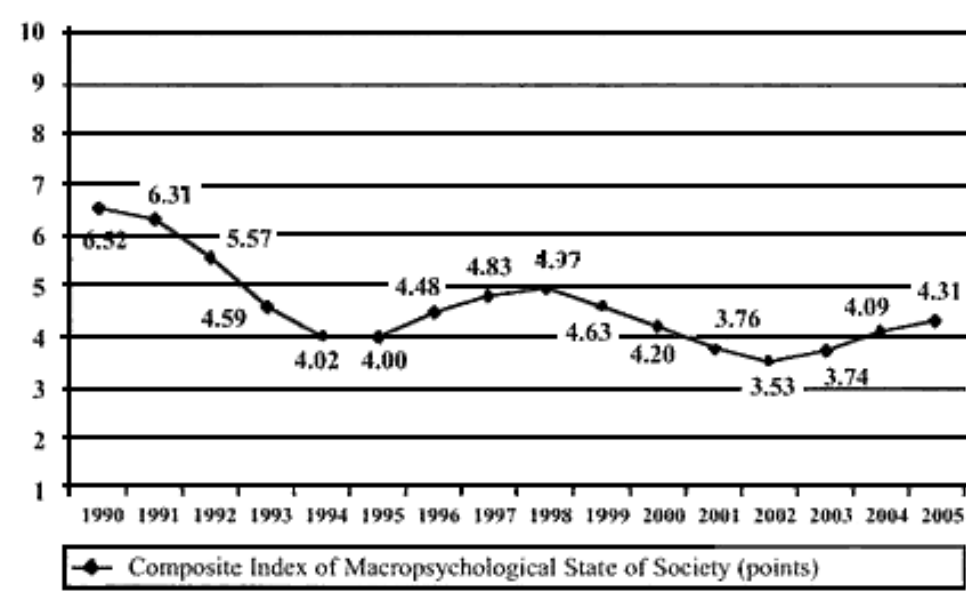

Source: The authors' calculations.

Figure 3. Dynamics of the Psychological Slate of Russian Society during $t$ he Reform Years

is characterized by a certain uplift in this dimension" (Petrenko, 2005, p. 387-388). V. Petrenko writes: "We may postulate that the feelings of despondency and apathy caused by the breakup of the existing way of life and system of values are gradually being replaced by an adaptation to the conditions of life and the discovery of new opportunities for a considerable part of our examinees (one would like to believe that it is a considerable portion of the population as well). If this tendency is correct, a turning point is possible (at least, a psychological one) in how people rationalize their own life in the post-perestroika period" (Ibid, p. 388).

But 1998 brought a financial default that involved the deterioration in material status of a considerable part of the population as well as a buildup of mistrust towards the authorities, a massive feeling of social instability, etc ${ }^{8}$. The default caused a new wave of deterioration in the

${ }_{8}$ In consequence, it would be wrong to consider the default that left a significant part of Russians both without money and confidence in the emerging stabilization as a purely economic event. Its social and psychological consequences were in no way less than the economic ones.
Russian society's psychological state. O. Dudchenko and A. Mytil write: "The incipient stabilization resulting from the first wave of adaptation was destroyed by this crisis (the default. $-A$. Yu., D. U.). The society faced the problem of re-adaptation once again" (Dudchcnko, and Mytil, 2001, p. 620). The psychological state of Russian society continued to deteriorate till 2002, when the situation in the country became more or less stable and new adaptation mechanisms took shape. After that it started improving again. Thus, the psychological state of Russian society measured with the help of the composite index, showed some keen reactions to changes in progress in the country. At the same time, it was lagging somewhat behind the economic and sociopolitical events, because the population needs some time to adapt to them and "digest" them psychologically.

In this context, we may postulate at least three mutually complementing mechanisms whereby the events taking place in society can influence the psychological state of its members. The first mechanism is a direct impact. If a person fall victim to reforms, a financial meltdown, crime, etc., this affects his or her psychological state in the most direct and "material" fashion. The second mechanism is impacting via expectations. A person may avoid falling victim to social collisions, losing money on his bank account or coming into contact with criminality but, considering a high probability of all that, he or she will live in constant fear, and this will also tell on their psychological state. Finally, the third mechanism is about this: even if events in society do not affect us directly, we cannot be impassive towards them anyway. A good case in point is the emotional state of utter psychological discomfort that engulfs us as we observe injustice (Adams, 1965).

In spite of a certain improvement of the situation in Russia in recent years that are denoted by the word "stabilization", the main reasons that used to cause anxiety in Russians in the 1990s persist to this day. In consequence, though there is a tendency lately towards an improvement in the psychological state of the Russian society, it is still far from being satisfactory. This is proved by the fact that, as is evident from Fig. 4, it even now fails to reach the average level (i.e., five points). Another evidence to this effect is a comparison of the appropriate indicators in Russia and a number of other countries, including Ukraine and Belarus (Fig. 4).

Comparing Russia with the two said CIS countries, that are its near twins in mentality and other characteristics, shows that the psychological 


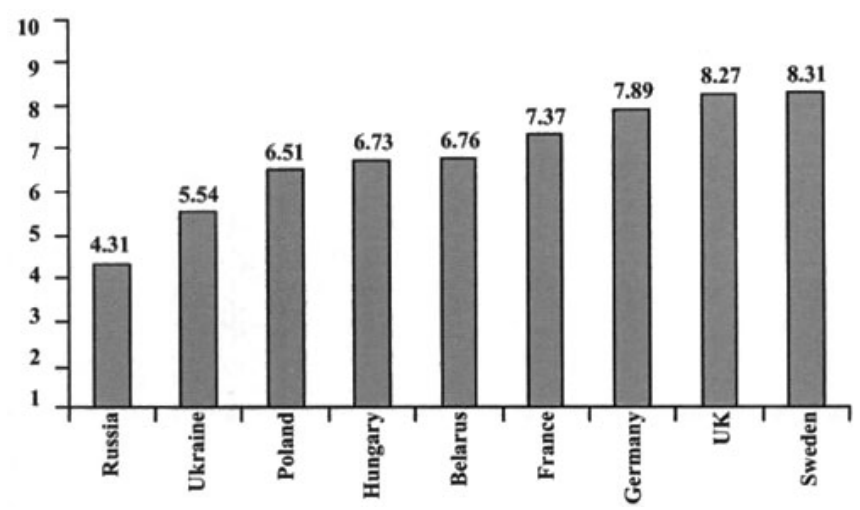

Figure 4. Composite Index of the Macropsychological State of Russia, 2005, and Foreign Countries, 2003-2004 (Points)

state of society is not a linear function of its economic state. For example, Russia boasts a higher standard of living than those countries but the citizens in those countries do not perish in terrorist attacks, they live with less crime-ridden regimes, etc., something that, along with a number of other noneconomic factors, takes care of a better psychological state ${ }^{9}$.

This picture is confirmed by comparative data on the social optimism level in four countries: Russia, Ukraine, Belarus and Kazakhstan. Writes E. Balatsky, who made the comparison: "The hierarchy in accordance with the social optimism level is this: Kazakhstan, Ukraine, Belarus, Russia. Thus, anxiety about the future is most clearly seen among the Russians". He states: "The social optimism gap we revealed is quite significant. For example, the difference between the appropriate indexes for Kazakhstan and Russia is almost $20 \mathrm{pp}$ (percentage points - A.Yu., D.U.). This advantage that one country enjoys over the other should be classified as the one of principle" (Balatsky, 2005b). Based on this data, Balatsky divides the UES (Unified Economic Space) countries into two categories: countries dominated by social optimism (Kazakhstan and Ukraine), and countries dominated by social pessimism (Belarus and Russia).

9 Obviously, in the case of Belarus, which is regularly accused of a lack or even total absence of democracy, the great stability of the existing sociopolitical regime is a factor, something that demonstrates the complex, not univocal, connection between the "amount" of democracy and the psychological well-being of citizens.

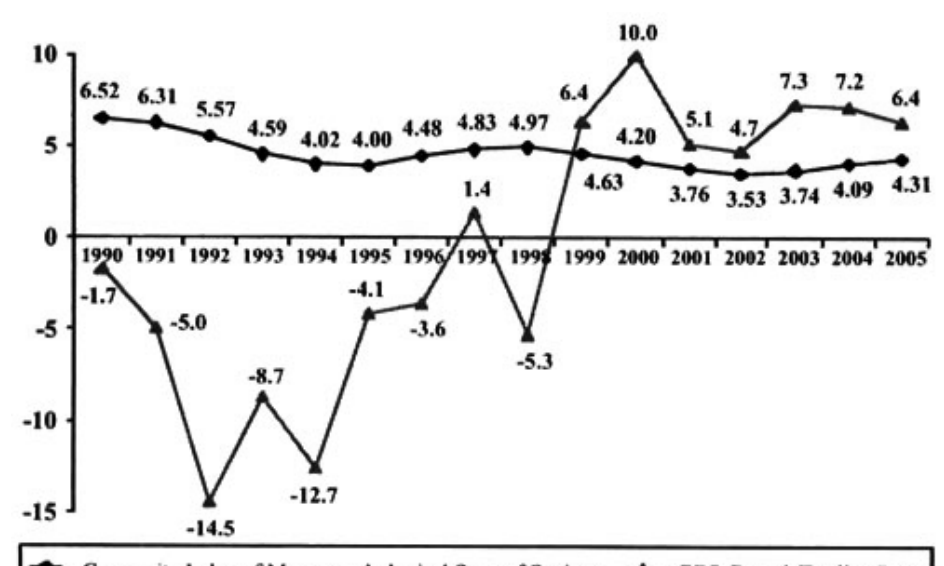

$\leftarrow$ Composite Index of Macropsychological State of Society

GDP Growth/Decline Rates

Figure 5. Composite Index of Macropsychological State of Russian Society as Compared with GDP Growth/Decline Rates

Let us note in this connection that we, Russians, traditionally compare ourselves with the West, taking it for the point of departure while we estimate whatever happens in this country. As a rule, our estimates are pessimistic but we implicitly assume that the former "fraternal republics" are even worse off than we are. The above data demonstrates that this assumption is erroneous and that we are far behind not only the Western countries but also Kazakhstan, where the social optimism level is concerned.

The lack of a linear link between society's economic and psychological states is also revealed by a comparison of the dynamics characterizing the appropriate indexes (Fig. 5).

As can be seen from Fig. 5, the compared indexes reveal essentially different dynamics. For example, between 1999 and 2000, an economic improvement was combined with a slide in the macropsychological state index, whereas a different picture was observed in 1998. This serves as yet another refutation of "economic determinism". It also bears witness to the fact that, firstly, growing macroeconomic indicators can far from always influence the life of the main part of the population, secondly, economic improvements in society cannot cause positive social and psychological changes right away, and, thirdly, so- 
Correlation of the Composite Index of the Macropsychological Table 2 of Russian Society with Its Social and Economic Indicators

\begin{tabular}{|c|c|}
\hline Social and Economic Indicators & Pearson Correlation Coefficient \\
\hline Natural population growth & 0.958 \\
\hline Gini coefficient (income concentration index) & -0.907 \\
\hline Number of registered crimes & -0.740 \\
\hline GDP growth/decline rates & -0.415 \\
\hline Life expectancy & 0.943 \\
\hline Number of "first registered" alcoholics & -0.963 \\
\hline
\end{tabular}

Source: The authors' calculations.

ciety's psychological state reflects not only its economic state but also many other things.

The second claim can be formulated as a general law. In particular, "economic consequences, as is evident from Western experiences, are leveled much faster than the consequences of a personality's social maladjustment" (Zhuravlyova, 2001, p. 509). Consequently, it is difficult to expect high viability and psychological well-being from a society that, though demonstrating annual GDP growth, lives in an atmosphere ridden with crime, economic and political instability ${ }^{10}$, lack of social and physical protection of the majority, moral degradation, and the like. One can hardly disagree with this observation: "The feeling of stability the majority used to enjoy earlier gave way, in many, to hopelessness, depression and a feeling that one had become a social outcast" (Kozyreva et al, 2001, p. 245). We concede, however, that it is an exaggeration to claim that "the phenomenon of feeling of stability of one's position... is absent in Russia" (Dudchenko, and Mytil, 2001, p. 618). A probe into main fears and anxieties that haunt the Russians demonstrates that the dominant ones are not only the fear of poverty but also the anxiety generated by lawlessness, growing crime rates, ethnic conflicts, etc (Shubkin, and Ivanova, 2001). However, it would be wrong to belittle the importance of macroeconomic indicators and their influence on the psychological

10 According to polls, the two most painful problems of the Russian society are economic and political instability as well as family material status (Balatsky, 2005a). state of society. Specifically, we have discovered a very high and clearly socially relevant negative correlation $(r=-0.907)$ between this state and the Gini coefficient (Table 2) defining differences in incomes between groups counting the ten richest and the ten poorest percent of the population in a nation. In other words, though the rates of the "common pie" (the GDP) grows, it places little influence to the psychological state of the main part of the population; it is how this "pie" is distributed and a resultant state of affairs that have substantial impact, and the bigger the disproportion in the level of incomes is, the worse is the psychological state of society.

As we can see from the Table, the society's psychological state reveals a close interconnection with most different aspects of its life. We will talk about that below.

\section{Creating a Viable Society}

The dynamics of the psychological state of the Russian society revealed with the help of the composite index is in agreement with the picture obtained on the basis of other indicators. For example, a sociological probe into dynamics of Russians' social self-disposition conducted with the help of an appropriate index that included the subindexes of (1) status identification and (2) satisfaction with and stability of existence, made it possible to reveal the following picture (See: Table 3) (Kozyreva et al., 2001, p. 248).

Table 3

Distribution of Respondents in Accordance with Social Self-Disposition Index $(\%)^{11}$

\begin{tabular}{|c|c|c|c|c|c|c|}
\hline Social Self-Disposition & 1994 & 1995 & 1996 & 1998 & 2000 & 2005 \\
\hline Poor and very poor & 39.5 & 40.1 & 38.9 & 45.9 & 28.5 & 19.9 \\
\hline Average & 35.5 & 33.9 & 34.9 & 32.6 & 35.4 & 32.4 \\
\hline Fine and very fine & 25.0 & 26.0 & 26.2 & 21.5 & 36.1 & 47.7 \\
\hline
\end{tabular}

Source: P. Kozyreva, S. Gerasimova, I. Kiseleva, A. Nizamova, "Dynamics of Russians' Social Self-Disposition," Russia: Society in Course of Transformation, Moscow, 2001, p. 243-255 and others (in Russian).

\footnotetext{
$\overline{11}$ Share (percentage) of respondents providing the corresponding answer.
} 
Comparison of the index of Russians' self-feeling in 1994-2000, as calculated by sociologists, and the index of macropsychological state of the Russian society demonstrates that they were changing practically simultaneously, showing an improvement from 1994 to 1998, a deterioration from 1998 to 2000 (after the default and, as the sociologists believe, because of it), and an improvement again after 2000. At the same time, the social self-feeling index "upped" in 2000 whereas our own index did the same later (2002). Clearly, both indexes are perceptive of similar tendencies but the "softer" tool used by the sociologists is likely to be more sensitive, registering the changes that manifest themselves at the level of statistical indicators underlying our own index, but it occurs somewhat later.

The sociological probe simultaneously demonstrated that it was 1998 when the highest level of anxiety over uncertainty of existence in the entire period under consideration was recorded. This sheds light on one of the main socio-psychological consequences of such economic events as the meltdown (default). Specifically, $83 \%$ of the respondents at that time expressed anxiety in connection with instability of their life (Kozyreva et al., 2001, p. 243-255). It should be mentioned, however, that there were $78 \%$ (Ibid.) of these in the relatively favorable (nondefault) year of 1996, while the mass feeling of instability is one of the main attributes of the Russian society as it is today, something confirmed by other polls.

Let us note one more thing. Even though the sociologists point to "a certain 'brightening' of the general emotional background in society" (Ibid., p. 250), the data they obtained demonstrates that only $15-20 \%$ of Russians have hopes for the better. It means there is light at the end of the tunnel, but the tunnel itself is still pretty dark. We must add that the conclusion they drew - "For all the ambiguity of the sources and content of the pessimistic world perception that colored the consciousness of fairly large masses of the population, their dissatisfaction with life's changes is the basis for sociopsychological discomfort and a deterioration of their social self-disposition" (Ibid., p. 252) - looks no less pessimistic than the worldview they described.

Other probes also confirm that a massive dissatisfaction with life as one of the main characteristics of modern Russian society has emerged. For example, those "fully satisfied with their life" amounted to a mere $3.8 \%$ in 1999 , while "rather dissatisfied" and "totally dissatisfied" - to $53.4 \%$. Moreover, $67.8 \%$ of those polled were "not sure" or "totally not sure" of their future (Shubkin, and Ivanova, 2001), which, naturally enough, told upon their psychological state. The general conclusion drawn in the above study is even more pessimistic if not downright alarmistic: "Almost two-thirds of Russia's population is in a state of grave anxiety. Figures characterize the catastrophic consciousness of the population" (Ibid, p. 358). True enough, later the number of Russians satisfied with their life grew (it corresponds to an improvement in the psychological state of society estimated with the help of the composite index), reaching, according to some calculations, 53\% (Balatsky, 2005a). Currently, "it is more correct to estimate Russians' self-disposition as boundary - ' $50 \times 50$ '12, but the number of those dissatisfied is very considerable as before ${ }^{13}$.

It makes sense to collate the psychological state of Russian society with such an indicator as the number of accidental alcoholic poisonings (Fig. 6). Comparing appropriate indicators demonstrates that they change practically simultaneously, too. It means that any deterioration in society's psychological state is accompanied by a rise in the number of lethal alcoholic poisonings. A huge number of deaths occasioned by falsified alcohol can, of course, be explained by such reasons as its poorly controlled production, the amorality of a considerable part of Russian entrepreneurs who do not care how they make money, the low living standards enjoyed by the people who tend to consume the cheapest and patently surrogate spirits, etc. But similar dynamics of alcoholic poisonings and the psychological state of society warrants the assumption that psychological hopelessness accompanied by health neglect is contribut-

12 The researcher who obtained this data specifies, however, that the number of those satisfied might be overstated (Balatsky, 2005a, p. 48).

13 Naturally, these general Russian tendencies reveal differences between various categories of respondents. For example, there is a greater share of those satisfied among men than women. For men, the more important factors determining satisfaction with life are those "directly aimed at life support", while "women pay more attention to personal security, material status, family relations, weather and climatic conditions of life, ecology, social infrastructure and state of health" (Ibid., p. 50). Certainly, the rich are more often satisfied with life than the poor, although they are not always pleased with it either, etc. (Ibid.). There is an interesting conclusion about how megalopolises influence satisfaction with life: "The megalopolises (Moscow and St. Petersburg) bring a destructive influence to bear on all aspects of people's satisfaction. On the contrary, major urban settlements with more than 0.5 million inhabitants bring a favorable influence" (Ibid., p. 51). 


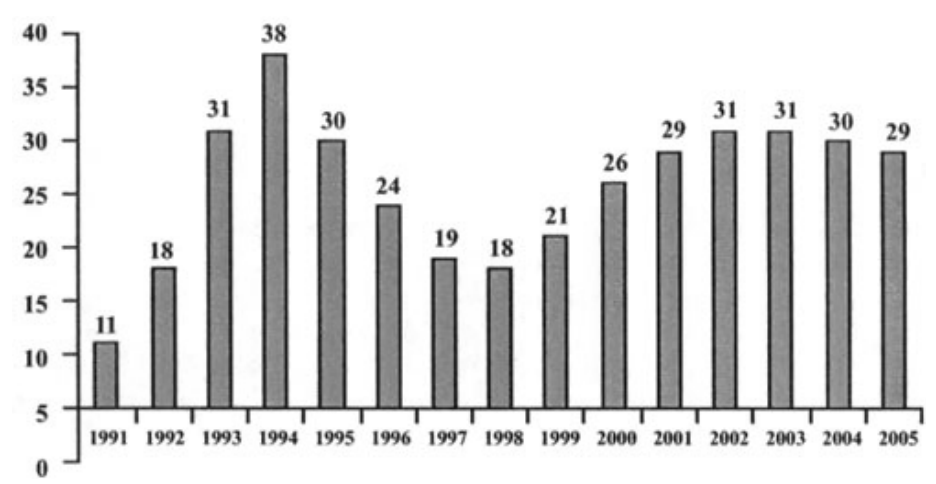

Figure 6. Mortality from Accidental Alcoholic Poisonings per 10,000 of the Population, 1991-2005

ing to this sad statistics. By contrast, any improvement in the psychological state of society can induce more caring attitudes of the citizens to their personal health, something that is confirmed by the high negative correlation we revealed between the index of the macropsychological state of Russian society and the alcoholism incidence statistics ( $r=$ -0.963) (Table 2).

Testifying in favor of precisely this interpretation of alcoholic poisonings is also the fact that the choice of hard liquor was much more modest in 1991 than, say, in 2000. The prices of "noble" drinks seemed exorbitant to the overwhelming majority of the population, and many Russians kept moonshine distilling devices at home, a natural upshot of a general shortage and Gorbachev's anti-alcoholic campaign. But the number of poisonings at that time was twice as small as in 2000 when there was no shortage of hard liquor. Accordingly, as the main reason we see mass attitudes to their personal health that change along with the psychological state of society, not the availability of liquor.

There is an identical tendency where drug addiction is involved. In our view, the conclusion that "the peculiarities of current socioeconomic processes in Russia promote an intensive development of marginality and, accordingly, the growth of drug addiction" (Pozdnyakova, 2001, p. 543) can be complemented with the assertion that the growth of drug addiction and alcohol abuse is aided not only by socioeconomic processes but also by the psychological state of Russian society. In this con- nection, it is appropriate to mention sociological data to the effect that alcohol abuse, drug addiction and suicides are largely fueled by such societal characteristic as a low level of social security (Mozgovaya, 2001) as well as social discontent. To quote Yu. Krasin, "protest is expressed by withdrawing from public life into the sphere of crime, drug addiction, alcoholism, mysticism and religious fanaticism. This form of protest is... destructive" (Krasin, 2006, p. 974).

Of course, the unsatisfactory psychological state of modern Russian society has political consequences as well. In 1994, for example, when its deterioration reached its first peak, $43 \%$ of Russians believed that this country lacked the conditions for democracy because the principles of Western democracy were incompatible with Russian traditions. From 1989, when the country was gripped by a "democratic euphoria", to 1996, when "the democratic uplift gave way to fatigue and apathy" (Ibid., p. 975), the share of those supporting the concentration of power in strong hands grew from $42 \%$ to $68 \%$, that is, to a patent majority of the population. In 1998, when psychological deterioration peaked for the second time, more than a quarter of those polled $-26.5 \%-$ spoke out in favor of a dictatorship (Weber et al, 2001). Other polls that are systematically run by Russian sociological centers as well as psychological studies (Shestopal, 2002) demonstrate similar results. In the mid-1990s, those displeased with the general course of Russia's development ("we have gone astray", etc.) constituted the absolute majority (Kinsbursky, 2001). Even after the election of a new President who, as was largely correctly hoped would stabilize the country, the share of disgruntled people believing that "events are leading us the wrong way, towards an impasse" was stably in excess of 50\% (Ibid.). The so-called "political absenteeism" expressed in growing ballot evasion, one of the chief indicators of mass apathy and lack of confidence in the authorities and political institutions, was building up till the start of 2000, too (Weber et al., 2001).

In this connection, it makes sense to recall one repeatedly confirmed fact that was described in textbooks on political science, namely: democracy is not an absolute value even for inhabitants of Western countries, who accept it depending on how it can benefit each of them personally (Mozgovaya, 2001; Petrenko 2005; and others). If a person does not feel any positive consequences of democracy personally for himself, or if its negative impacts on his personal life outweigh the positive ones, democracy tends to lose its positive associations - with freedom, human digni- 
ty, etc. - and starts being perceived in a negative light. This is happening in Russia, too, where politicians' incantations about the self-value of democracy and their attempts to revive in the people's memory the horrors of totalitarianism increasingly often seem like the cry in the desert.

Thus, despite some positive tendencies surfacing during the last few years, the psychological state of Russian society, as estimated with the help of the composite index, remains utterly unsatisfactory, something confirmed by other data as well. Better economic indicators and measures like the authorities' national projects have little impact on the psychological state so far. The lack of any radical improvement in the psychological state of the Russian citizens will inevitably entail an increase in mass-scale anomie, sociopolitical passivity, distrust of the authorities, as well as, in all evidence, a buildup of alcohol abuse and drug addiction, further population decline, etc. To curb these tendencies, economic growth per se is clearly not enough; radical and effective measures are needed, aimed at improving the psychological state of the Russians. It is also necessary to bring consistent pressure to bear on factors eroding this state. Clearly, the time has come to recognize the inadequacy of "economic determinism" and substantially modify the views on society and social processes that formed the basis of the Russian reforms. Russia's development record during the 15 years of reforms convincingly demonstrated that "the seeming advantages of the course for achieving economic efficiency at any cost are planting the time bombs under longterm development prospects". A more fitting strategic goal - "creating a viable society in a viable and ecologically stable environment" (Weber et al, 2001, p. 196) - implies to recognize the importance of society's psychological state.

It should be noted in conclusion that the economic measures to encourage birthrates (mother allowances, etc.) can increase them, according to our calculations, by no more than $15 \%$, while the typical answer to the question, why people do not wish to have children is this: We do not want to procreate children in a country like this one. For all that, "it can be seen that the authorities understand that the social and personal values are important, but where decision-making and choice of managerial actions are concerned, things mostly come down to the sociomaterial factor again and again. But there is still no answer to the question, why state managerial actions, designed to influence all, including other, factors, are not found" (Sulakshin, 2006, p. 23).
The intention to procreate a child implies a psychologically complex decision that, as a rule, is accepted when a family enjoys psychological well-being (Boyko, 1985). The macropsychological state of Russian society displays a very high correlation with natural population growth $(r=0.958)$ and life expectancy $(\mathrm{r}=0.943)$ (Table 2). In other words, one of the main causes behind the tendency towards the "dying out" of Russia's population that has been quite acute over the recent years is its psychological state. As long as it is not radically improved, one can hardly expect that this tendency, which is one of the main national problems of Russia, will be surmounted.

\section{References}

Adams, J.S. (1965). Inequity in Social Exchange. In L. Berkowitz (ed.). Advances in Experimental Social Psychology, vol. 2. New York.

Balatsky, E.V. (2005a). Faktory udovletvorennosti zhizn'yu: izmerenie i integral'nye pokazateli [Factors of Being Satisfied with One's Own Life: Measurement and Integral Indicators]. Monitoring obshestvennogo mneniya, 4. P. 42-52.

Balatsky, E.V. (2005b). Metody diagnostiki social'nogo samochuvstviya naseleniya [Methods to Diagnose Social Self-Disposition of the Population]. Monitoring obshchestvennogo mneniya, 3. P. 47-53.

Biderman, A. (1970). A Social Indicator, Whence and Whither? Washington.

Boyko, V.V. (1985). Rozhdaemost': Social'no-psihologicheskie aspekty' [Birthrates. Sociopsychological Aspects]. Moskva: My`sl’.

Dudchenko, O.N., and Mytil, A.V. (2001). Dve modeli adaptacii k social'nym izmeneniyam [Two Models for Adaptation to Social Changes]. In Rossiya: transformiruyushheesya obshhestvo [Russia: Society in Course of Transformation]. Moskva: Kanon-Press-Cz. P. 607-620.

Gaidar, Ye.T. (2006). Gibel' imperii. Uroki dlya sovremennoj Rossii [The Fall of an Empire. Lessons for Modern Russia]. Moskva.

Gundarov, I.A. (2001). Demograficheskaya katastrofa $v$ Rossii: prichiny, mehanizmy, puti preodoleniya [A Demographic Disaster in Russia: Causes. Mechanisms. Ways of Overcoming It]. Moskva: URSS.

Keltner, D. et al. (1993). The Influence of Attributions on the Relevance of Negative Feelings to Personal Satisfactions. Personality and Social Psychology Bulletin, 19.

Kinsburskiy, A.V. (2001). Social'noe nedovol'stvo i obshestvennoe povedenie [Social Discontent and Public Behavior]. In Rossiya: transformiruyushheesya obshhestvo [Russia: Society in Course of Transformation] Moskva: Kanon-Press-Cz. P. 335-347. 
Kozyreva, P. et al. (2001). Dinamika social'nogo samochuvstviya rossiyan [Dynamics of the Russians' Social Self-Disposition]. In Rossiya: transformiruyushheesya obshhestvo [Russia: Society in Course of Transformation] Moskva: Kanon-Press-Cz. P. 243-255.

Krasin, Yu.P. (2006). Politicheskie aspekty social'nogo neravenstva [Political Aspects of Social Inequality]. Vestnik Rossyiskoy Akademii nauk, 11. P. 971-977.

Mozgovaya, A.V. (2001). Posledstviya bedstvii i katastrof [Consequences of Calamities and Disasters]. In Rossiya: transformiruyushheesya obshhestvo [Russia: Society in Course of Transformation] Moskva: Kanon-Press-Cz. P. 563-575.

Petrenko, V.F. (2005). Osnovy psihosemantiki [Foundations of Psychosemantics]. Sankt-Peterburg: Piter.

Pozdnyakova, M.E. (2001). Social'nye i psihologicheskie posledstviya narkotizacii [Social and Psychological Consequences of Drug Proliferation]. In Rossiya: transformiruyushheesya obshhestvo [Russia: Society in Course of Transformation] Moskva: Kanon-Press-Cz. P. 532-545.

Rats, M.V. (1997). Ideya otkrytogo obshhestva $v$ sovremennoi Rossii [The Idea of Open Society in Modern Russia]. Moskva: Magistr.

Shestopal, E.B. (2002). Obrazy vlasti v Rossii konca XX veka. Nekotorye rezul'taty issledovaniya 1993-2002 gg. [Images of Power in Late 20th-century Russia. Certain Results of Investigations 1993-2002]. In Psihologiya vospriyatiya vlasti [Psychology of Perception of Power], vypusk 1. Moskva: SP Mysl'

Shubkin, V.N., and Ivanova, V.A. (2001). Strahi, trevogi, sposobnost' protivostoyat' im [Fears, Anxieties, Ability to Withstand]. In Rossiya: transformiruyushheesya obshhestvo [Russia: Society in Course of Transformation] Moskva: Kanon-Press-Cz. P. 348-358.

Sulakshin, S.S. (2006). Rossiiskii demograficheskii krizis: ot diagnostiki $k$ preodoleniyu [Russian Demographic Crisis: From Diagnosing to Overcoming]. Moskva: Nauchnyj ekspert.

Weber, A.B. et al. (2001). Tendencii politicheskogo razvitiya Rossii [Tendencies in Russia's Political Development]. In Rossiya: transformiruyushheesya obshhestvo [Russia: Society in Course of Transformation] Moskva: Kanon-Press-Cz. P. 180-198.

Yurevich, A.V. (2006). Social'naya relevantnost' i social'naya nisha psihologii [Social Relevance and Psychology's Social Niche]. Psikhologicheskiy zhurnal, 4. P. 5-14.

Zhuravlyova, I.V. (2001). Social'nye faktory uhudsheniya zdorov'ya naseleniya [Social Factors of the Population's Health Deterioration]. In Rossiya: transformiruyushheesya obshhestvo [Russia: Society in Course of Transformation] Moskva: KanonPress-Cz. P. 506-519. 